MOTA, LCBM; TEBALDI, ND; LUZ, JMQ. 2021. Occurrence of Pseudomonas fluorescens and P. putida associated to tomato pith necrosis in Brazil. Horticultura Brasileira 39: 258-263. DOI: http://dx.doi.org/10.1590/s0102-0536-20210303

\title{
Occurrence of Pseudomonas fluorescens and P. putida associated to tomato pith necrosis in Brazil
}

\section{Lara Caroline BM Mota ${ }^{1} \mathbb{D}$; Nilvanira D Tebaldi ${ }^{1} \mathbb{D} ;$ José Magno Q Luz ${ }^{1 \mathbb{D}}$}

${ }^{1}$ Universidade Federal de Uberlândia, Instituto de Ciências Agrárias (UFU-ICIAG), Uberlândia-MG, Brasil; lara.moreira@ufu.br; nilvanira. tebaldi@ufu.br; jmagno@ufu.br

\begin{abstract}
In 2016, several reports emerged of fresh-market staked tomato plants with severe symptoms of pith necrosis and premature death in commercial cultivation areas in the states of Paraná and Minas Gerais, Brazil, which are similar to those caused by Pseudomonas corrugata. Four bacterial strains were isolated from infected tissue samples and characterized as Gram-negative, aerobic, and fluorescent on King's B Medium. LOPAT tests were performed and the isolate UFU H120 was classified into group $\mathrm{Vb}(++-+-)$ and the isolates UFU H3, UFU H6, and UFU H21 into group Va $(-+-+-)$. The pathogenicity of the isolates was confirmed by artificial inoculation on tomato plants of Santa Cruz type, cv. Kada Gigante, and Koch's postulates were accomplished successfully. The isolates sequences of their 16S rRNA gene region were compared with those deposited in GenBank, the isolate UFU H120 aligning with Pseudomonas fluorescens (99,45\% similarity) and the isolates UFU H3, UFU H6, and UFU H21 with Pseudomonas putida (99.2, 99.53 and 99.64\% similarity, respectively). Notably, P. fluorescens and P. putida are most known as saprophytic bacteria normally present in the soil, although both of these species have already been reported to infect tomato plants in Italy. However, so far, there have not been any reports of such bacteria being phytopathogenic on tomato or any crop in Brazil. Thus, to our knowledge, this is the first report of pith necrosis of such occurrence in Brazil.
\end{abstract}

Keywords: Solanum lycopersicum, fluorescent Pseudomonas, pith necrosis.

\section{RESUMO}

Ocorrência de Pseudomonas fluorescens e Pseudomonas putida em tomateiro no Brazil

Em 2016 em tomateiro tutorado para consumo in natura, foram observadas plantas com sintomas graves de necrose da medula e morte prematura da planta, em áreas de cultivo comercial nos estados do Paraná e Minas Gerais, Brazil, similares aos causados por Pseudomonas corrugata. Quatro cepas bacterianas foram isoladas a partir de amostras de tecido infectado e caracterizadas como Gram negativas, crescimento aeróbico e fluorescimento em meio de cultura King B. Testes LOPAT foram realizados e o isolado UFUH120 foi classificado no grupo $\mathrm{Vb}\left(+++_{-}+-\right)$e isolados UFU H3, UFU H6 e UFU H21 no grupo Va (- + - + -). A patogenicidade dos isolados foi confirmada pela inoculação artificial em tomate Santa Cruz cv. Kada Gigante e os postulados de Koch realizados com sucesso. O sequenciamento da região do gene $16 \mathrm{~S}$ rRNA dos isolados foi realizado e as sequências obtidas comparadas com as depositadas no GenBank, o isolado UFU H120 foi alinhado com Pseudomonas fluorescens (99.45\% de similaridade) e os isolados UFU H3, UFU H6 e UFU H21 com Pseudomonas putida (similaridades de 99,2, 99,53 e 99,64\%, respectivamente). Pseudomonas fluorescens e $P$. putida são mais conhecidas como bactérias saprofíticas presentes no solo, embora as duas espécies tenham sido relatadas na Itália, causando doença no tomateiro. No entanto, até o momento não há relatos que essas bactérias sejam fitopatogênicas no tomate ou em qualquer cultura no Brasil. Sendo este, por parte do conhecimento dos autores, o primeiro relato da ocorrência dessas espécies causando necrose da medula em lavouras de tomateiro no país.

Palavras-chave: Solanum lycopersicum, Pseudomonas fluorescentes, necrose da medula.

\section{Received on October 16, 2020; accepted on June 15, 2021}

$\mathrm{P}$ th necrosis is a tomato (Solanum lycopersicum) disease caused by different bacteria belonging to the genus Pseudomonas. The disease is important because results in yellowing of the leaves, and impaired development of the plant that may be related to lower productivity (Monteiro et al., 2019).

The species Pseudomonas cichorii (Wilkie \& Dye, 1974; Trantas et al., 2013), P. corrugata (Scarlett et al., 1978;
Clark \& Watson, 1986), P. viridiflava (Alivizatos, 1986; Malathrakis \& Goumas, 1987), Pseudomonas fluorescens (Malathrakis \& Goumas, 1987; Lo Cantore \& Iacobellis, 2002; Saygili et al., 2004; Polizzi et al., 2007), Pseudomonas mediterranea (Catara et al., 2002; Trantas et al., 2015), Pseudomonas putida (Polizzi et al., 2007; Dimartino et al., 2011), and P. marginalis (Bella \& Catara, 2010;
Kudela et al., 2010) have already been reported causing pith necrosis in tomato plant, and also Xanthomonas perforans in association with $P$. fluorescens, $P$. marginalis, $P$. putida, P. citronellolis, and $P$. straminea (Aiello et al., 2013).

In Brazil, the pith necrosis caused by Pseudomonas corrugata (Rodrigues Neto et al., 1989; Quezado-Duval et al., 2007), P. mediterranea (Rodrigues et al., 2010), and P. viridiflava (Monteiro 
et al., 2019) have been reported. Other species of Pseudomonas are associated to leaf diseases on tomatoes, such as Pseudomonas syringae pv. tomato, $P$. syringae pv. syringae, $P$. cichorii, $P$. marginalis, and $P$. viridiflava (Beriam, 2007; Maringoni et al., 2009).

In 2016, in the states of Paraná and Minas Gerais, Brazil, in commercial staked tomato cultivation isolated plants displayed severe symptoms of pith necrosis. Symptoms were similar to those described by Dimartino et al. (2011) and Aiello et al. (2013), such as lower leaf withering that progresses upwards, extensive pith necrosis, leaf chlorosis, dark-brown lesions, longitudinal stem cracks, adventitious root growth and premature plant death.

Morphological, physiological and biochemical tests can be used to identify plant pathogenic bacteria. A panel of biochemical (LOPAT) is recommended for the genus Pseudomonas (Lelliott \& Stead, 1987; Schaad et al., 2001). However, these tests are not always sufficient for a precise identification of the species or pathovar associated to a given plant disease. This is because of the great biochemical and genetic diversity of the species; more than 100 species described in genus, as well as the possible emergence of new species or pathovars that have not been previously described for the crop or repositioning of species in the taxon (Garrido-Sanz et al., 2016).

For the identification of Pseudomonas species, molecular techniques based on genomic analysis can be used, such as PCR with specific primers, already described for $P$. syringae pv. tomato, $P$. corrugata, and $P$. syringae pv. syringae (Bereswill et al., 1994; Catara et al., 2000; Hamedan \& Harighi, 2014). When this type of identification is not possible, genetic sequencing of the $16 \mathrm{~S}$ region (16S rRNA) with universal primers (James, 2010), and comparison of allelic mismatches in housekeeping genes by MLSA(Vásquez-Ponce et al., 2018) can be applied for bacterial identification. The comparison of nucleotide sequences in the 16S rRNA gene encoding region, and housekeeping genes are useful to study bacterial phylogeny, because the genes are considered preserved among bacteria, but with genetic variability (Yang et al., 2016; Vásquez-Ponce et al., 2018). Thus, the aim of this study was to identify Pseudomonas spp. isolates causing tomato pith necrosis in Brazil.

\section{MATERIAL AND METHODS}

This study was conducted at the Laboratory of Plant Bacteriology (LABAC) and at the greenhouse of the Institute of Agricultural Sciences (ICIAG) of the Federal University of Uberlândia (UFU), Umuarama Campus (Uberlândia-MG, Brazil), from November 2016 to December 2019.

\section{Obtained isolates}

In 2016, in the states of Paraná and Minas Gerais, Brazil, in open field commercial cultivation areas staked tomatos plants were observed with severe symptoms of pith necrosis and premature death, similar to those described for Pseudomonas corrugata. Bacterial isolation was performed from four infected tomato plant tissues with severe necrotic symptoms on the pith region of stem basis (Figures 1A, 1B, 1C) from Araguari-MG (UFU H3, UFU H6); Silvestre-PR (UFU H21); and Uberlândia-MG (UFU H120). All isolates were grown in culture medium 523 (Kado \& Heskett, 1970) for two to three days at $28^{\circ} \mathrm{C}$.

\section{Biochemical characterization of isolates}

All colony isolates were morphologically characterized by visual observation or, when necessary, using a stereomicroscope. Characteristics such as color, shape, edges or margins, elevation, texture or consistency, and optical details were analyzed (Mariano \& Silveira, 2005). They were also characterized using the identification key proposed by Schaad et al. (2001): Gram with $\mathrm{KOH}$ tests, oxidation/ fermentation $(\mathrm{O} / \mathrm{F})$ and fluorescence in King B medium. The species belonging to the genus Pseudomonas were identified using the LOPAT specific tests: levan, oxidase, potato rot, arginine dehydrolase, and hypersensitivity in tobacco plants (Lelliott \& Stead, 1987;
Schaad et al., 2001).

\section{Pathogenicity of isolates}

The pathogenicity of the isolates was confirmed by inoculating a bacterial suspension of each isolate into healthy Santa Cruz Kada Gigante tomato plants kept in a greenhouse when they presented two trifoliate leaves. Each bacterial suspension was standardized on a spectrophotometer with an absorbance of $0.2(540 \mathrm{~nm})$, resulting in an approximate concentration of 1 $\times 10^{8} \mathrm{CFU} \mathrm{mL}^{-1}$ (Andrade et al., 2013). Inoculation was performed by injecting $100 \mu \mathrm{L}$ of the bacterial suspension into axillary first true leaves of plantlets at the two leaves stage using a sterile hypodermic syringe. Control plants were mock inoculated with sterile distilled water and all plants were kept in a moist chamber for $24 \mathrm{~h}$ before and after inoculation. Six plants were inoculated for each isolate. After 10 days of inoculation, the plants were examined, with stem cross section for the presence of discoloration and pith necrosis. The bacteria were reisolated to fulfill Koch's postulates and characterized using the LOPAT biochemical tests.

\section{DNA extraction}

Genomic DNA extractions were performed following the manufacturer's protocol, Wizard Genomic DNA Purification Kit (Promega, Madison, WI, USA). The DNA obtained from each isolate was quantified using a NanoDrop 2000/2000c 192 Spectrophotometers apparatus (Thermo Fisher Scientific, Wilmington, DE, USA), with the concentration adjusted to $25 \mathrm{ng} \mu \mathrm{L}^{-1}$.

Polymerase Chain Reaction with specific primers for Pseudomonas spp.

Polymerase chain reactions were performed with specific primers for $P$. corrugata, $P$. syringae pv. tomato and P. syringae pv. syringae. Primers PC5/1 (5'-CCA CAG GAC AAC ATG TCC AC-3') and PC5/2 (5'-CAG GCG CTT TCT GGAACA TG- $3^{\prime}$ ) were used for $P$. corrugata (Catara et al., 2000). The final volume of each reaction was $12.5 \mu \mathrm{L}$, with the final concentration including $1 \times$ buffer $(500 \mathrm{mM} \mathrm{KCl}$ and $200 \mathrm{mM}$ Tris- $\mathrm{HCl}, \mathrm{pH} 8.4), 3 \mathrm{mM} \mathrm{MgCl}_{2}, 0.2 \mathrm{mM}$ 
dNTP, $0.4 \mu \mathrm{M}$ PC5/1 and PC5/2, 1.25U of Taq polymerase, and $25 \mathrm{ng}$ of DNA. Amplification was performed in a thermocycler with denaturation at $95^{\circ} \mathrm{C}$ for $5 \mathrm{~min}$, followed by 30 cycles at $94^{\circ} \mathrm{C}$ for $30 \mathrm{~s}, 62^{\circ} \mathrm{C}$ for $30 \mathrm{~s}$, and $72^{\circ} \mathrm{C}$ for $1 \mathrm{~min}$, and fragment amplification was visualized at $1,100 \mathrm{bp}$.

Primers 1 (5'-GGC GCT CCC TCG CAC TT- $\left.3^{\prime}\right)$ and 2 (5'-GGT ATT GGC GGG GGT GC-3') were used for $P$. syringae pv. tomato (Bereswill et al., 1994). The final volume of each reaction was $12.5 \mu \mathrm{L}$, with the final concentration including $1 \times$ buffer $(500 \mathrm{mM} \mathrm{KCl}$ and $200 \mathrm{mM}$ Tris-HCl, $\mathrm{pH} 8.4$ ), $3 \mathrm{mM}$ $\mathrm{MgCl}_{2}, 0.2 \mathrm{mM}$ dNTP, $2 \mu \mathrm{M}$ Primers 1 and 2, $1 \mathrm{U}$ of Taq polymerase, and $50 \mathrm{ng}$ of DNA. Amplification was performed in a thermocycler, with 30 cycles at $95^{\circ} \mathrm{C}$ for $30 \mathrm{~s}, 60^{\circ} \mathrm{C}$ for $30 \mathrm{~s}$, and $72^{\circ} \mathrm{C}$ for $45 \mathrm{~s}$, followed by a final extension step at $72^{\circ} \mathrm{C}$ for $5 \mathrm{~min}$, and fragment amplification was visualized at $650 \mathrm{pb}$.

Primers PF (5'-GCG CGG TCT TGT TTC GGG GA-3') and PR (5'TCT CGC AGC TCC TCG CCC AT-3') were used for $P$. syringae pv. syringae (Hamedan \& Harighi, 2014). The final volume of each reaction was $12.5 \mu \mathrm{L}$, with the final concentration including $1 \times$ buffer $(500 \mathrm{mM} \mathrm{KCl}$ and $200 \mathrm{mM}$ Tris-HCl, $\mathrm{pH}$ 8.4), $3 \mathrm{mM} \mathrm{MgCl}, 0.2 \mathrm{mM}$ $\mathrm{dNTP}, 2 \mu \mathrm{M}$ Primers PR and PF, $1 \mathrm{U}$ of Taq polymerase, and $50 \mathrm{ng}$ of DNA. Amplification was performed in a thermocycler, with denaturation at $93^{\circ} \mathrm{C}$ for $3 \mathrm{~min}$, followed by 35 cycles at $93^{\circ} \mathrm{C}$ for $1 \mathrm{~min}, 63^{\circ} \mathrm{C}$ for $1 \mathrm{~min}$, and $72^{\circ} \mathrm{C}$ for $1 \mathrm{~min}$, followed by a final extension step at $72^{\circ} \mathrm{C}$ for $6 \mathrm{~min}$, and fragment amplification was visualized at $576 \mathrm{bp}$.

The final products of the reactions were analyzed using electrophoresis on $1 \%$ agarose gel stained with SYBR Safe, and the amplified fragments were visualized using an ultraviolet light transilluminator and photodocumented

\section{Gene sequencing of the $16 \mathrm{~S}$ region}

The $16 \mathrm{~S}$ region of the isolates was sequenced using PCR with primers $27 \mathrm{~F}$ (5'-AGA GTT TGA TCM TGG CTC AG- $\left.3^{\prime}\right)$ and 1492R (5'-TAC GGH TAC CTT GTT ACG ACT T-3') (MartinLaurent et al., 2001). The final volume of each reaction was $50 \mu \mathrm{L}$, with the final concentration including $1 \times$ buffer, $3 \mathrm{mM} \mathrm{MgCl}, 0.2 \mathrm{mM}$ dNTP, $1 \mu \mathrm{M}$ Primers $27 \mathrm{~F}$ and $1492 \mathrm{R}, 1.25 \mathrm{U}$ of Taq polymerase, and $50 \mathrm{ng}$ of DNA. Amplification was performed in a thermocycler, with denaturation at $94^{\circ} \mathrm{C}$ for $5 \mathrm{~min}$, followed by 40 cycles at $94^{\circ} \mathrm{C}$ for $1 \mathrm{~min}, 56^{\circ} \mathrm{C}$ for $1 \mathrm{~min}$, and $72^{\circ} \mathrm{C}$ for $2 \mathrm{~min}$, followed by a final extension step at $72^{\circ} \mathrm{C}$ for $15 \mathrm{~min}$, and fragment amplification was visualized at $1,492 \mathrm{bp}$.

All PCR products were sent for sequencing at BPI Biotecnologia EPP (Botucatu-SP, Brazil). The obtained sequences were then submitted to the BLAST platform of the National Center for Biotechnology Information (NCBI) and compared with the genetic sequences available in the GenBank database (NCBI, 2019).

\section{RESULTS AND DISCUSSION}

The bacterial colonies of the isolates were morphologically characterized in culture medium 523 as circular, shiny, smooth-edged, slightly elevated, transparent and straw-white-colored colonies (Figure 1D). The isolates were Gram-negative, aerobic, fluorescent on King B medium, and were classified as Pseudomonas (Schaad et al., 2001). From the LOPAT tests, the isolate UFU H120 was classified into group $\mathrm{Vb}(+$ $+-+-)$ as Pseudomonas fluorescens, whereas the isolates UFU H3, UFU H6 and UFU H21 were identified into group Va $(-+-+-)$ as Pseudomonas putida (Lelliott \& Stead, 1987).

Pith necrosis symptoms (Figures 1E, $1 \mathrm{~F})$ were observed in the tomato plants 10 days after inoculation, confirming the pathogenicity of the isolates. No symptoms were observed in the mock inoculated control plants.

The genomic DNA of the isolates was not amplified with specific primers for P. corrugata, P. syringae pv. tomato, and $P$. syringae pv. syringae. The sequences of the 16S rRNA gene region were compared with those deposited in GenBank. Notably, the isolate UFU H120 was closely aligned with $P$. fluorescens (GenBank no. LC031819.1) with $99.45 \%$ similarity and $100 \%$ sequence query coverage. The isolates
UFU H3, UFU H6, and UFU H2 1 were closely aligned with $P$. putida (GenBank no. NR_114794.1) with 99.2, 99.53, and $99.64 \%$ similarity, respectively, and $100 \%$ sequence query coverage.

Pseudomonas putida and $P$. fluorescens are saprophytic bacteria (Lelliot \& Stead, 1987) commonly present in the soil in Brazil (Cabral et al., 2013; Ferraz et al., 2015; Aponte et al., 2017; Sousa et al., 2019), but until now, no phytopathogenic activity associated with these species has been described, and also have not been described in the Absent Quarantine Pest List (A1) of the Ministry of Agriculture, Livestock and Food Supply (Mapa, 2018). These species have already been reported to cause pith necrosis in Europe (Lo Cantore \& Iacobellis, 2002; Saygili et al., 2004; Polizzi et al., 2007; Dimartino et al., 2011), although the bacteria transmission by the seeds was not described up to now. Hence, it is important to investigate this new emergence, because Brazil is one of the top ten producers of tomatoes worldwide (Faostat, 2019) and the pith necrosis caused by $P$. fluorescens or P. putida is a serious disease that can significantly decrease crop productivity (Aiello et al., 2017).

The symptoms caused by $P$. fluorescens and P. putida are identical, as well as those of the pith necrosis caused by $P$. corrugata (Quezado-Duval et al., 2007), thus requiring laboratory analysis to differentiate them. Such symptoms include lower leaf wilting that progresses upwards, extensive pith necrosis at the base of the plant, leaf chlorosis, dark-brown lesions, longitudinal stem cracks, adventitious root growth, and premature plant death, which are similar to the symptoms described by Aiello et al. (2013).

Generally, Pseudomonas spp. are common inhabitants of the aerial parts of plants, soil, and the rhizosphere; act as beneficial antagonistic bacteria against several phytopathogens; and are frequently used in biological control strategies (Lugtenberg \& Kamilova, 2009). However, some P. fluorescens and $P$. putida isolates may become pathogenic or interact synergistically with other pathogens, increasing the 
disease severity (Aiello et al., 2017).

Notably, the incidence of pith necrosis in Italy in 2006 was attributed to changes made in cultivation practices after discontinuing the use of methyl bromide. Although the non-use of the pesticide has been environmentally beneficial, to increase the number of saprophytic species in the soil, they were believed to have induced a phytopathogenic behavior in $P$. fluorescens and P. putida (Dimartino et al., 2011). In addition, several environmental conditions, including high specific humidity, salinity, temperature changes and excessive nitrogen, increase the development of opportunistic species (Lo Cantore \& Iacobellis, 2002). Although the bacteria transmission by the seeds has not been described until now, the hypothesis is that the bacteria could be introduced in Brazil by the seeds, but this must be investigated.

Characterization and correct identification of $P$. fluorescens and $P$. putida can improve the management of such disease in the field, especially since the symptoms of pith necrosis in tomato plants can be confused with the symptoms caused by other species of fluorescent Pseudomonas, such as $P$. mediterranea and P. viridiflava, species described in Brazil. This could help improving the understanding of the pathogenic mechanisms involved in infection (Rodrigues et al., 2010; Dimartino et al., 2011; Monteiro et al., 2019). Pseudomonas spp. exhibit a high level of diversity, allowing the occurrence of species or pathovars that have not been previously reported to exhibit phytopathogenicity, as a result of changes in their genome and adaptation to local conditions (Aiello et al., 2013).

After a reporting of $X$. perforans causing also pith necrosis in tomato plants (Aiello et al., 2013), Torelli et al. (2015) have compared the putative coding sequences of the $X$. perforans strain $4 \mathrm{P} 1 \mathrm{~S} 2$, if unusual pathogenic behavior was due to newly acquired molecular determinants or by environment causes. The authors observed that the genome of strain 4P1S2 has high sequence similarity with that one non-vascular strain, but shows

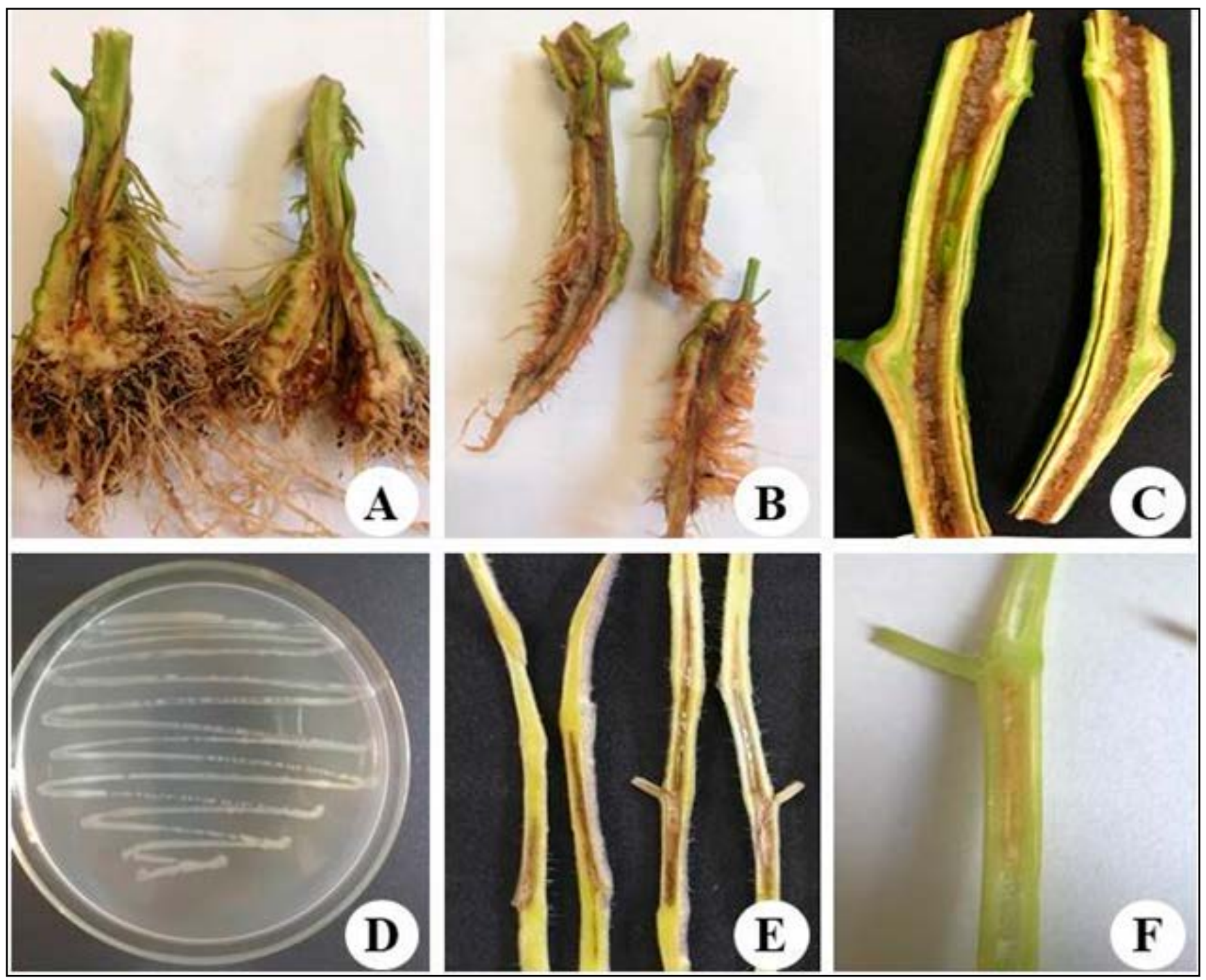

Figure 1. Pith necrosis in tomato plants, observed in open field, caused by the Pseudomonas putida (A, B), and Pseudomonas fluorescens (C). Bacterial colony of the P. putida isolate UFU H3 in culture medium 523 after three days at $28^{\circ} \mathrm{C}$ (D). Pith necrosis in tomato plant 10 days after inoculation with P. putida isolate UFU H6 (E), and P. fluorescens isolate UFU H120 (F). Uberlandia, UFU, $2016-2019$. 
evidences of an additional sequence, possibly contained on a conjugative plasmid that acts in the horizontal transfer of genes originating from vascular Xanthomonas spp. The authors have inferred also, that the ability to cause a vascular disease can be not only due to genome, but due to the environment, because of the coinfection with endophytic microorganisms, since Pseudomonas species were also found in the same infection site caused by $X$. perforans (Aiello et al., 2013, 2017).

In this sense, the sequencing of housekeeping genes, related to cellular metabolism and essential for the survival of the microorganism, by Multilocus Sequence Typing (MLST) and Multilocus Sequence Analysis (MLSA) has allowed the phylogenetic studies and identification of new species of Pseudomonas. The MLST consists of comparing allelic mismatches in housekeeping genes and MLSA in the analysis concatenated sequence of these genes (Sarkar \& Guttman 2004; Martens et al., 2007; Ribeiro et al., 2009; Vásquez-Ponce et al., 2018).

The MLST of seven housekeeping genes (acn, cts, gapA, gyrB, pfk, pgi, rpoD) from $P$. syringae, from different patovars and hosts, identified 40 sequences with high congruence, indicating a common evolutionary history and the specific association of the patovars with the host occurs by a small genetic variation (Sarkar \& Guttman, 2004). Also with MLST of four housekeeping genes (cts, gapA, gyrB, rpoD) from 216 strains of $P$. syringae, phytopathogenics and saprophytics, 23 clades within 13 phylogroups were identified, demonstrating that the citrate synthase (cts) housekeeping gene can accurately predict the phylogenetic affiliation for more than $97 \%$ of strains tested (Berge et al., 2014).

In the biochemical, morphological and the molecular characterization (repPCR and MLSA the housekeeping genes gyrB, rpoD and rpoB) of 15 isolates of $P$. cichorii cause tomato pith necrosis in Greece, Trantas et al. (2013) described a new genomovar of $P$. cichorii, being the strains phylogenetically differentiable but phenotypically indistinguishable. In a similar study, the MSLA of the housekeeping genes aroE, glnS, gyrB,
ileS and rpoD, also including the $16 \mathrm{~S}$ rRNA gene, from Pseudomonas isolates from Antartica, identified a new strain of Pseudomonas mandelii and three new species from the Pseudomonas fluorescens subgroup (Vásquez-Ponce et al., 2018).

More in-depth phylogenetic studies, including MLST and MLSA, are needed to compare the $P$. putida and $P$. fluorescens isolates of this study, with isolates of soil opportunists and phytopathogenic, to analyze the DNA changes that enabled them to infect plants. This is considered to be possible, given that the DNA sequences in the $16 \mathrm{~S}$ rRNA gene and the housekeeping genes, despite having a faster rate of evolution than ribosomal genes, are conserved in bacteria, yet exhibits enough variability and information to clearly show the phylogenetic and evolutionary relationships between the species (Ribeiro et al., 2009; Yang et al., 2016).

To our knowledge, this is the first occurrence of $P$. fluorescens and $P$. putida causing pith necrosis on staked tomato crops in Brazil. All isolates were deposited in the phytobacteria culture collection at the ICIAG/UFU Laboratory of Bacteriology under the codes UFU H3, UFU H6, UFU H21 ( $P$. putida), and UFU H120 (P. fluorescens).

\section{ACKNOWLEDGMENTS}

We thank the Fundação de Apoio Universitário (FAU) of the Federal University of Uberlândia (UFU) Uberlândia-MG, Brazil; the Conselho Nacional de Desenvolvimento Científico e Tecnológico (CNPq); Coordenação de Aperfeiçoamento de Pessoal de Nível Superior (CAPES) and Fundação de Amparo à Pesquisa do Estado de Minas Gerais (FAPEMIG), for funding this research.

\section{REFERENCES}

AIELLO, D; SCUDERI, G; VITALE, A; FIRRAO, G; POLIZZI, G; CIRVILLERI, G. 2013. A pith necrosis caused by Xanthomonas perforans on tomato plants. European Journal of Plant Pathology 137: 29-41.

AIELLO, D; VITALE, A; RUOTA, AD; POLIZZI,
G; CIRVILlERI, G. 2017. Synergistic interactions between Pseudomonas spp. and Xanthomonas perforans in enhancing tomato pith necrosis symptoms. Journal of Plant Pathology 99: 731-740.

ALIVIZATOS, AS. 1986. Tomato pith necrosis caused by Pseudomonas viridiflava. Annales de 1'Institut Phytopathologique Benaki 15: 41-47.

ANDRADE, CCL; RESENDE, RS; RODRIGUES, FA; SILVEIRA, PR; RIOS, JA; OLIVEIRA, JR; MARIANO, RLR. 2013. Indutores de resistência no controle da pinta bacteriana do tomateiro e na atividade de enzimas de defesa. Tropical Plant Pathology 38: 28-34.

APONTE, A; CASTILlO, O; CABRERA, G; PERNIA, M; HERNANDEZ, Y. 2017. Rhizobacteria Pseudomonas fluorescens and Azospirillum sp. association enhances growth of Lactuca sativa L. under tropical conditions. Journal of Central European Agriculture 18: 424-440.

BELLA, P; CATARA, V. 2010. Occurrence of tomato pith necrosis caused by Pseudomonas marginalis in Italy. Plant Pathology 59: 402.

BERESWILL, S; BUGERT, P; VOLKSCH, B; ULLRICH, M; BENDER, CL; GEIDER, K. 1994. Identification and relatedness of coronatine-producing Pseudomonas syringae pathovars by PCR analysis and sequence determination of the amplification products. Applied and Environmental Microbiology 60: 2924-2930.

BERGE, O; MONTEIL, CL; BARTOLI, C; CHANDEYSSON, C; GUILBAUD, C; SANDS, DC; MORRIS, CE. 2014. A user's guide to a data base of the diversity of Pseudomonas syringae and its application to classifying strains in this phylogenetic complex. PloS ONE 9: e105547.

BERIAM, LOS. 2007. Doenças bacterianas em hortaliças. Biológico 69: 81-84.

CABRAL, L; GIOVANELLA, P; GIANELLO, C; BENTO, FM; ANDREAZZA, R; CAMARGO, FAO. 2013. Isolation and characterization of bacteria from mercury contaminated sites in Rio Grande do Sul, Brazil, and assessment of methylmercury removal capability of a Pseudomonas putida V1 strain. Biodegradation 24: 319-331.

CANTORE, P; IACOBELLIS, NS. 2002. Necrosi corticale e delmidollo del pomodoro causata da Pseudomonas fluorescens in Puglia. Informatore Fitopatologico 52: 54-57.

CATARA, V; ARNOLD, D; CIRVILLERI, G; VIVIAN, A. 2000. Specific oligonucleotide primers for the rapid detection of the causal agent of tomato pith necrosis, Pseudomonas corrugata: evidence for two genomic groups. European Journal of Plant Pathology 106: 753-762.

CATARA, V; SUTRA, L; MORINEAU, A; ACHOUAK, W; CHRISTEN, R; GARDAN, L. 2002. Phenotypic and genomic evidence for the revision of Pseudomonas corrugata and proposal of Pseudomonas mediterranea sp. nov. International Journal of Systematic and Evolutionary Microbiology v. 52: 1749-1758. 
CLARK, RG; WATSON, DRW. 1986. New plant disease record in New Zealand: Tomato pith necrosis caused by Pseudomonas corrugata. New Zealand Journal of Agricultural Research 29: 105-109.

DIMARTINO, M; PANEBIANCO, S; VITALE, A; CASTELLO, I; LEONARDI, C; CIRVILLERI, G; POLIZZI, G. 2011. Occurrence and pathogenicity of Pseudomonas fluorescens and P. putida on tomato plants in Italy. Journal of Plant Pathology 93: 79-87.

FERRAZ, HGM; MILAGRES, EA; MOREIRA, PC; ROMEIRO, RS. 2015. Métodos de dispensa do antagonista Pseudomonas putida (UFV-0073) no biocontrole da manchabacteriana e pinta-bacteriana do tomateiro. Revista Brasileira de Ciências Agrárias 10: 123-127.

FOOD AND AGRICULTURE ORGANIZATION OF THE UNITED NATIONS- FAOSTAT. 2019. Statistic of agricultural production 2017. Available at: http://www.fao.org/faostat/ en/\#data/QC/visualize. Accessed November 21, 2019.

GARRIDO-SANZ, D; MEIER-KOLTHOFF, JP; MGÖKER, M; MARTÍN, M; RIVILLA, R; REDONDO-NIETO, M. 2016. Genomic and genetic diversity within the Pseudomonas fluorescens complex. PloS ONE 11: $\mathrm{e} 0150183$.

HAMEDAN, E; HARIGHI, B. 2014. Genetic diversity of Pseudomonas syringae pv. syringae strains, causing bacterial stem blight disease of alfalfa in the kurdistan province of Iran. Journal of Plant Pathology 96: 303-307.

JAMES, G. 2010. Universal bacterial identification by PCR and DNA sequencing of 16S rRNA gene. In: SCHULLER, M; SLOOTS, TP; JAMES, GS; HALLIDAY, CL; CARTER, IWJ (eds). PCR for Clinical Microbiology. v. 876. London, UK: Springer. P.209-214.

KADO, EI; HESKETT, MG. 1970. Selective media for isolation of Agrobcterium, Corynebacterium, Erwinia, Pseudomonas and Xanthomonas. Phytopathology 60: 969-976.

KUDELA, V; KREJZAR, V; PÁNKOVÁ, I. 2010. Pseudomonas corrugata and Pseudomonas marginalis associated with the collapse of tomato plants in rockwool slab hydroponic culture. Plant Protection Science 46: 1-11.

LELLIOTT, RA; STEAD, DE. 1987. Methods for the diagnosis of bacterial diseases of plants. London, England: Oxford-Blackwell Scientific Publications. 216p.

LUGTENBERG, B; KAMILOVA, F. 2009. Plant-growth-promoting rhizobacteria. Annual Review of Microbiology 63: 541-556.

MALATHRAKIS, NE; GOUMAS, DE. 1987. Bacterial soft rot of tomato in plastic greenhouses in Crete. Annals of Applied Biology 111: 115-123.

MARIANO, RLR; SILVEIRA, EB. 2005. Manual de práticas em fitobacteriologia. Recife, Brazil: Universidade Federal Rural de
Pernambuco. 184p.

MARINGONI, AC; GIORIA, R; KOBORI, RF; AZEVEDO, SM; PIERI, C; SILVA JUNIOR, TAF. 2009. Occurrence of Pseudomonas viridiflava on tomato in Brazil. Journal of Plant Pathology 91: 504.

MARTENS, M; DELAERE, M; COOPMAN, R; VOS, P; GILLIS, M; WILLEMS, A. 2007. Multilocus sequence analysis of Ensifer and related taxa. International Journal of Systematic and Evolutionary Microbiology 57: 489-503.

MARTIN-LAURENT, F; PHILIPPOT, L; HALLET, S; CHAUSSOD, R; GERMON, JC; SOULAS, G; CATROUX, G. 2001. DNA extraction from soils: old bias for new microbial diversity analysis methods. Applied and Environmental Microbiology 67: 2354-2359.

MINISTÉRIO DAAGRICULTURA PECUÁRIA E ABASTECIMENTO- MAPA. 2018. Pragas Quarentenárias Ausentes - PQA. Instrução Normativa $\mathrm{n}^{\circ} 39$, de 1 de outubro de 2018 D.O.U no 190, Seção 1, pgs. 11-14, 2/10/2018. Available at: http://www.in.gov.br/ materia/-/asset_publisher/Kujrw0TZC2Mb/ content/id/43460217/do1-2018-10-02instrucao-normativa-n-39-de-1-de-outubrode-2018-43460055. Accessed November 4, 2019.

MONTEIRO, FP; OGOSHI, C; BECKER, WF; WAMSER, AF; VALMORBIDA, J. 2019. Pith necrosis associated with Pseudomonas viridiflava in tomato plants in Brazil. Plant Pathology \& Quarantine 9: 1-5.

N A T I O N A L C E N T ER F O R BIOTECHNOLOGY INFIRMATIONNCBI. 2019. Nucleotide Blast. Available at: https://blast.ncbi.nlm.nih.gov/Blast. cgi?PAGE_TYPE=BlastSearch\&BLAST SPEC $=$ MicrobialGenomes. Accessed November 21, 2019.

POLIZZI, G; DIMARTINO, M; PANEBIANCO, S; CIRVILLERI, G. 2007. A new emergence on soilless tomato cultures in Sicily: vascular and pith discoloration caused by Pseudomonas fluorescens and P. putida. Journal of Plant Pathology 89: 54-55.

QUEZADO-DUVAL, AM; GUIMARÃES, CMN; MARTINS, OM. 2007. Occurrence of Pseudomonas corrugata causing pith necrosis on tomato plants in Goiás, Brazil. Fitopatologia Brasileira 32: 6.

RIBEIRO, RA; BARCELLOS, FG; THOMPSON, FL; HUNGRIA, M. 2009. Multilocus sequence analysis of Brazilian Rhizobium microsymbionts of common bean (Phaseolus vulgaris $\mathrm{L}$.) reveals unexpected taxonomic diversity. Research in Microbiology 160: 297-306.

RODRIGUES, LMR; DESTÉFANO, SAL; BERIAM, LOS; RODRIGUES-NETO, J. 2010. Occurrence of Pseudomonas mediterranea on tomato in Brazil. Plant Pathology 59: 797.

RODRIGUES NETO, J; MALAVOLTA JUNIOR, VA; RAMOS, R. 1989. Ocorrência de Pseudomonas corrugata em tomateiro no Estado de São Paulo. Summa Phytopathologica 15: 20.

SARKAR, SF; GUTTMAN, DS. 2004. Evolution of the core genome of Pseudomonas syringae, a highly clonal, endemic plant pathogen. Applied and Environmental Microbiology 70 : 1999-2012.

SAYGILI, H; AYSAN, Y; SAHIN, F; USTUN, N; MIRIK, M. 2004. Occurrence of pith necrosis caused by Pseudomonas fluorescens on tomato plant in Turkey. Plant Pathology 53: 803.

SCARLETT, CM; FLETCHER, JT; ROBERTS, P; LELLIOT, RA. 1978. Tomato pith necrosis caused by Pseudomonas corrugata nov. sp. Annals of Applied Biology 88: 105-14.

SCHAAD, NM; JONES, J; CHUN, W. 2001. Laboratory guide for identification of plant pathogenic bacteria. Saint Paul, USA: APS Press. $373 \mathrm{p}$.

SOUSA, IM; NASCENTE, AS; FILIPPI, MCC. 2019. Bactérias promotoras do crescimento radicular em plântulas de dois cultivares de arroz irrigado por inundação. Colloquium Agrariae 15: 140-145.

TORELLI, E; AIELLO, D; POLIZZI, G; FIRRAO, G; CIRVILLERI, G. 2015. Draft genome of a Xanthomonas perforans strain associated with pith necrosis. FEMS Microbiology Letters 362: 1-3.

TRANTAS, EA; SARRIS, PF; MPALANTINAKI, EE; PENTARI, MG; VERVERIDIS, FN; GOUMAS, DE. 2013. A new genomovar of Pseudomonas cichorii, a causal agent of tomato pith necrosis. European Journal of Plant Pathology 137: 477-493.

TRANTAS EA; SARRIS, PF; PENTARI, MG; MPALANTINAKI, EE; VERVERIDIS, FN; GOUMAS, DE. 2015. Diversity among Pseudomonas corrugata and Pseudomonas mediterranea isolated from tomato and pepper showing symptoms of pith necrosis in Greece. Plant Pathology 64: 307-318.

VÁSQUEZ-PONCE, F; HIGUERA-LLANTÉN, S; PAVLOV, MS; MARSHALL, SH; OLIVARES-PACHECO, J. 2018. Phylogenetic MLSA and phenotypic analysis identification of three probable novel Pseudomonas species isolated on King George Island, South Shetland, Antarctica. Brazilin jornal of microbiology 49: 695-702.

WILKIE, P; DYE, DW. 1974. Pseudomonas cichorii causing tomato and celery diseases in New Zealand. New Zealand Journal of Agricultural Research 17: 123-130.

YANG, B; WANG, Y; QIAN, P. 2016. Sensitivity and correlation of hypervariable regions in $16 \mathrm{~S}$ rRNA genes in phylogenetic analysis. $B M C$ Bioinformatics 17: 1-8. 